\title{
Pathophysiology, echocardiographic evaluation, biomarker findings, and prognostic implications of septic cardiomyopathy: a review of the literature
}

\author{
Robert R. Ehrman ${ }^{1 *}$, Ashley N. Sullivan², Mark J. Favot ${ }^{1}$, Robert L. Sherwin ${ }^{1}$, Christian A. Reynolds ${ }^{3}$, \\ Aiden Abidov ${ }^{4}$ and Phillip D. Levy ${ }^{5}$
}

\begin{abstract}
Background: Sepsis is a common condition encountered by emergency and critical care physicians, with significant costs, both economic and human. Myocardial dysfunction in sepsis is a well-recognized but poorly understood phenomenon. There is an extensive body of literature on this subject, yet results are conflicting and no objective definition of septic cardiomyopathy exists, representing a critical knowledge gap.

Objectives: In this article, we review the pathophysiology of septic cardiomyopathy, covering the effects of key inflammatory mediators on both the heart and the peripheral vasculature, highlighting the interconnectedness of these two systems. We focus on the extant literature on echocardiographic and laboratory assessment of the heart in sepsis, highlighting gaps therein and suggesting avenues for future research. Implications for treatment are briefly discussed.

Conclusions: As a result of conflicting data, echocardiographic measures of left ventricular (systolic or diastolic) or right ventricular function cannot currently provide reliable prognostic information in patients with sepsis. Natriuretic peptides and cardiac troponins are of similarly unclear utility. Heterogeneous classification of illness, treatment variability, and lack of formal diagnostic criteria for septic cardiomyopathy contribute to the conflicting results. Development of formal diagnostic criteria, and use thereof in future studies, may help elucidate the link between cardiac performance and outcomes in patients with sepsis.
\end{abstract}

Keywords: Echocardiography, Sepsis, Troponin, B-type natriuretic peptide, Ultrasound

\section{Background}

Septic cardiomyopathy (SC) is often diagnosed when some acute perturbation in cardiac function exists in the setting of sepsis. At present, no formalized or consensus definition of SC exists, representing a critical knowledge gap. Complexity of the cardiovascular system, myriad methods of assessment, and variations in the pre-septic state of the heart make elucidation of a cause-and-effect relationship difficult.

\footnotetext{
* Correspondence: rehrman@med.wayne.edu

${ }^{1}$ Department of Emergency Medicine, Wayne State University School of Medicine, Detroit Medical Center/Sinai-Grace Hospital, 4201 St. Antoine, Suite 3R, Detroit, MI 48201, USA

Full list of author information is available at the end of the article
}

SC has been recognized for 40 years [1,2] and may be present in up to $44 \%$ of patients [3, 4], but it remains incompletely understood. While results are varied, some studies suggest that mortality is two to three times greater when SC is present $[5,6]$. Understanding how the heart behaves is critical when making treatment decisions for septic patients. For example, aggressive fluid resuscitation has been integral in the treatment of sepsis for nearly two decades, but recent literature suggests that excessive fluid resuscitation is deleterious in some patients [7, 8]. Variations in myocardial performance could explain, at least in part, these observed differences.

Early studies utilized invasive assessment methods or radionuclide imaging [4, 9]; while providing a plethora

(c) The Author(s). 2018 Open Access This article is distributed under the terms of the Creative Commons Attribution 4.0 International License (http://creativecommons.org/licenses/by/4.0/), which permits unrestricted use, distribution, and 
of data, these techniques are of limited utility to emergency and critical care physicians given that they cannot be performed at the point-of-care and are difficult to repeat.

Echocardiography, however, is widely available, noninvasive, and easily repeatable, making it an optimal modality for evaluation of SC. Measurement of serum cardiac biomarkers provides separate, but related, information about the state of the heart [10] and thus may be complementary to echocardiographically derived data.

The purpose of this article is to review the extant literature on SC, with a focus on the evaluation and prognostic implications of various echocardiographic and laboratory measures thereof.

\section{Pathophysiology}

The pathophysiologic cascade of sepsis begins when the host immune system responds to an invading pathogen, resulting in activation of the innate immune response [11]. This culminates in the generation and release of proinflammatory mediators and signaling molecules that may be physiologic (beneficial) or pathologic (harmful) to the host; concomitant release of anti-inflammatory mediators occurs as well. These molecules, acting through varied signal transduction pathways, which in some cases alter gene expression, activate both positive and negative feedback loops within the immune system [12]. Recent advances in oxidative lipidomics have identified products of upstream lipid metabolism that are involved in the initiation (eicosanoids) and recovery phases (lipoxins, resolvins) [13]. Sepsis-induced dysregulation of the normal immune response can lead to a variety of deleterious effects, including SC, multi-system organ failure, and ultimately death in some patients [5] .

Septic shock is often classified as a type of "distributive" shock-relative hypovolemia resulting from maldistribution of circulating volume due to peripheral vasodilation, glycocalyx dysfunction, and increased capillary permeability. It has also been described as a biphasic disorder with an early, hyperdynamic phase (high cardiac output (CO), low systemic vascular resistance (SVR), warm extremities) and a late, hypodynamic phase (low $\mathrm{CO}$, poor perfusion) $[5,6]$. Circulating inflammatory mediators are believed to be the causative agents, acting directly on cardiomyocytes and the peripheral vasculature, which affects myocardial performance via alterations in SVR and venous return.

While preload augmentation has long been a primary intervention for sepsis and can increase $\mathrm{CO}$ via the FrankStarling mechanism, its ability to do so depends on the functional state of the heart. However, measures of preload, such as central venous pressure (CVP) and inferior vena cava (IVC) dimensions, provide limited information on underlying cardiac function. Even when volume responsiveness is suggested by low CVP, increased respiratory variation of IVC diameter, or other invasive methods, guidance of resuscitation based on these measures has not been found to improve outcomes [14-16].

Changes in afterload also affect the ability of the heart to deliver blood to the peripheral tissues. Thus, a heart with poor intrinsic contractility may be able to increase $\mathrm{CO}$ when SVR is low-thereby giving the impression of normal function-when in fact systolic performance is impaired. This dysfunction may only become apparent when SVR returns to normal via natural (recovery from sepsis) or artificial means (vasopressor use). Boissier et al. [17] demonstrated such an inverse relationship between ejection fraction and SVR in septic patients.

An early hypothesis, based on animal models, was that SC was caused by global myocardial ischemia resulting from decreased coronary blood flow [18]. Subsequent investigation, including human studies, showed preserved or increased coronary perfusion in some septic patients [19]. Derangements in cardiomyocyte physiology are still believed to play a role, but at the microcirculatory, rather than the macrocirculatory, level [20]. Inflammatory molecules are thought to be responsible for this via pleiotropic effects [5]. Damage occurs via changes in endothelial permeability, leading to edema, increased neutrophil transduction into the interstitium, fibrin deposition, and in some cases, activation of the coagulation cascade [21]. Increased oxidative stress may induce mitochondrial dysfunction and disruption of normal calcium handling [22] - critical events given the high-energy demands of cardiac tissue. The exact mechanism that culminates in cardiac dysfunction is not clear; one theory posits that myocardial edema leads to disruption or malfunction of the contractile apparatus [23]. Autonomic dysregulation leading to decreased expression of adrenergic receptors and thus resistance to endogenous catecholamines may also be present [22]. Figure 1 illustrates the complex interactions between host and pathogen factors that contribute to the development of SC.

Despite such pathology, a cardinal feature of SC is its apparent reversibility, with many studies reporting that patients' cardiac function recovered fully to their premorbid state $[1,5,20,24]$. Cardiac magnetic resonance has detected changes suggesting myocardial edema or an altered metabolic state, a pattern distinct from that seen with ischemia and necrosis, the former being consistent with reversibility [25]. Thus, some theorize that SC represents a protective "hibernating" state [26], as has been demonstrated in subsets of patients with acute myocardial ischemia [27]. A reversible-and incompletely understood-takotsubo pattern has also been described in septic patients. The physiologic stresses of sepsis are thought to play a role, but its place within the SC continuum is not clear given the paucity of extant data [28]. 


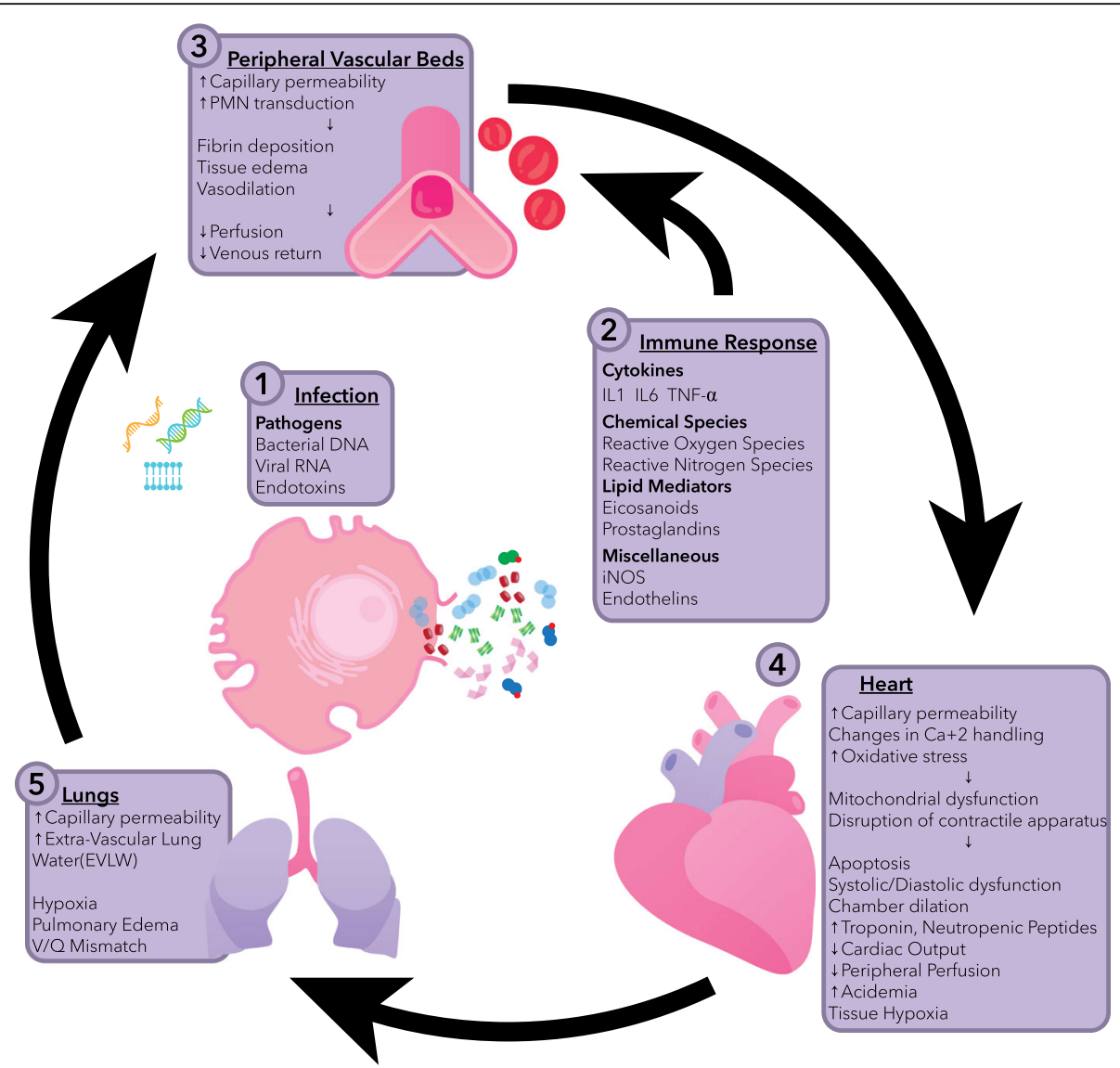

Fig. 1 Pathophysiology of septic myocardial dysfunction. IL interleukin, iNOS induced nitric oxide synthase, PMN polymorphonuclear cell, TNF tumor necrosis factor

\section{Echocardiography: diagnosis and prognosis}

A summary of the echocardiographic parameters that have been used in the evaluation of SC, and their limitations, is listed in Table 1. Table 2 summarizes the literature on echocardiography in SC discussed in the ensuing sections. According to GRADE guidelines [29], the quality of evidence on this topic is "low" or "very low". A summary of the major limitations within the literature on septic cardiomyopathy is provided in Table 3.

\section{Left ventricle: systolic function \\ Ejection fraction}

Systolic dysfunction, as measured by left ventricular ejection fraction (LVEF), was one of the first described parameters to assess for SC. Parker et al., in 1984 [1], reported that approximately $50 \%$ of their patients with septic shock had reduced LVEF. Counter-intuitively, they found low mean LVEF amongst survivors compared to non-survivors. Jardin et al. confirmed these findings [24] and further reported that LV parameters were unaffected by fluidloading in non-survivors. Unfortunately, several follow-up studies found no difference in LVEF between survivors and non-survivors of septic shock [30, 31]. Two recent meta- analyses that included 1247 patients failed to find any meaningful relationship between LV parameters and mortality in septic shock [32, 33].

\section{Global longitudinal strain}

Strain imaging is a novel technique based on regional myocardial deformation. The most frequently used strain parameter is global longitudinal strain (GLS), which represents the mean longitudinal strain value from each segment of the LV [34].

Most commonly, GLS is calculated using speckletracking echocardiography (STE) [35]. STE is a semiautomated, post-processing computer algorithm that tracks user-selected regions of the myocardium ("speckles") during the cardiac cycle. As fibers contract during systole, speckles move closer together, represented by negative values. Larger negative values represent greater deformation in systole and thus improved LV function (Fig. 2).

Strain imaging has the ability to detect subtle changes in LV systolic function prior to decline in LVEF [36]. A meta-analysis by Kalam et al. found that GLS was a better predictor of adverse outcomes, including mortality, than LVEF patients with heart failure and other cardiac 


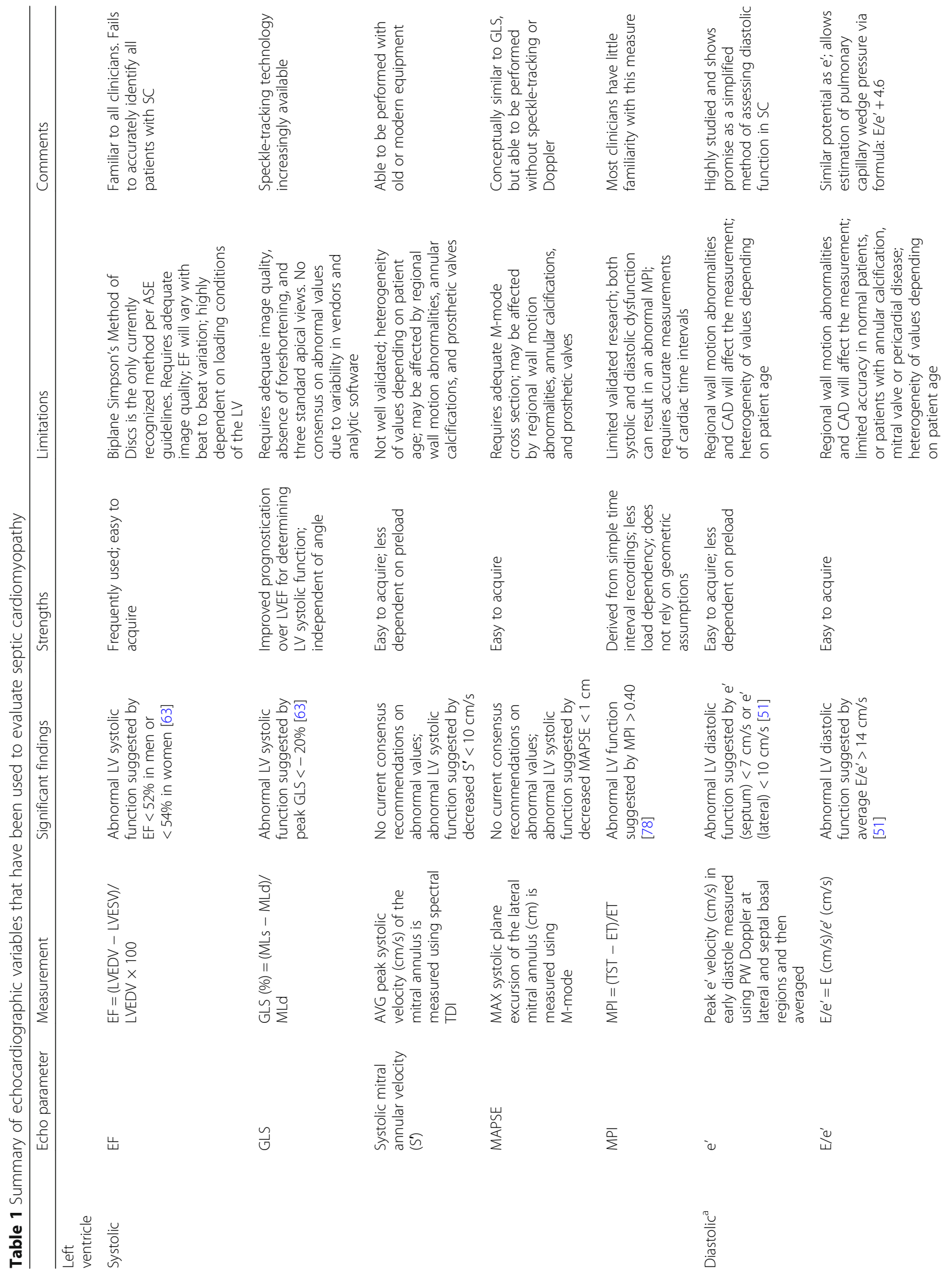




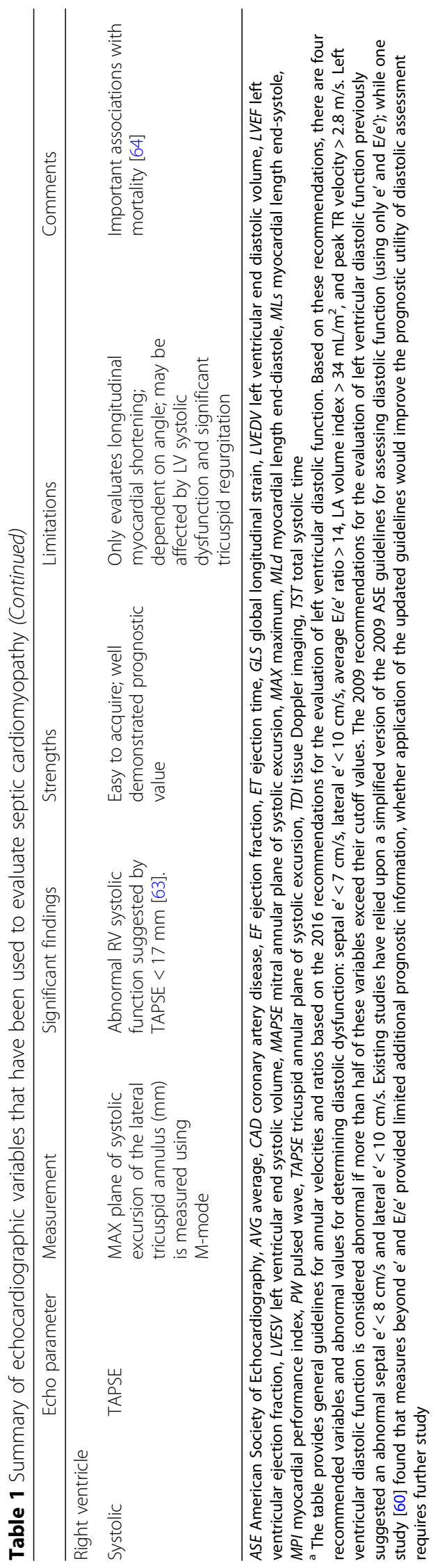


Table 2 Summary of selected articles on septic cardiomyopathy

\begin{tabular}{|c|c|c|c|c|c|c|}
\hline & $\begin{array}{l}\text { Echo } \\
\text { parameter }\end{array}$ & Study & $\begin{array}{l}\text { Study design/ } \\
\text { setting }\end{array}$ & $N$ & Measured outcome & Results \\
\hline \multicolumn{7}{|c|}{ Left ventricle } \\
\hline \multirow[t]{10}{*}{ Systolic } & EF & $\begin{array}{l}\text { Sevilla Berrios } \\
\text { et al. (2014) } \\
\text { [33] }\end{array}$ & Meta-analysis & 585 & $\begin{array}{l}\text { To evaluate the significance of } \\
\text { reduced LVEF in patients with } \\
\text { severe sepsis and septic shock. } \\
\text { Primary outcome was association } \\
\text { between depressed LVEF and } \\
\text { 30-day mortality }\end{array}$ & $\begin{array}{l}\text { Depressed LVEF had a } \\
\text { sensitivity of } 52 \% \text { ( } 95 \% \text { CI } \\
29-73 \% \text { ) and specificity of } 63 \% \\
\text { ( } 95 \% \text { CI } 53-71 \%) \text { for mortality } \\
\text { and was therefore not a } \\
\text { sensitive nor specific predictor } \\
\text { of mortality }\end{array}$ \\
\hline & & $\begin{array}{l}\text { Huang et al. } \\
\text { (2013) [32] }\end{array}$ & Meta-analysis & 762 & $\begin{array}{l}\text { To evaluate the association of } \\
\text { both reduced LVEF and increased } \\
\text { LV dimensions with mortality in } \\
\text { patients with severe sepsis and } \\
\text { septic shock }\end{array}$ & $\begin{array}{l}\text { No significant difference in } \\
\text { LVEF and LV dimensions in } \\
\text { survivors vs non-survivors }\end{array}$ \\
\hline & & $\begin{array}{l}\text { Jardin et al. } \\
\text { (1999) [24] }\end{array}$ & $\begin{array}{l}\text { Single-center } \\
\text { prospective cohort } \\
\text { study }\end{array}$ & 90 & $\begin{array}{l}\text { To evaluate changes in LV function, } \\
\text { including LVEF and LV volumes, } \\
\text { during volume resuscitation in patients } \\
\text { with septic shock }\end{array}$ & $\begin{array}{l}\text { LVEF was depressed in all } \\
\text { patients. LV parameters were } \\
\text { additionally unaffected by fluid } \\
\text { loading }\end{array}$ \\
\hline & & $\begin{array}{l}\text { Parker et al. } \\
\text { (1984) [1] }\end{array}$ & $\begin{array}{l}\text { Single-center } \\
\text { prospective cohort } \\
\text { study }\end{array}$ & 20 & $\begin{array}{l}\text { To evaluate cardiac function in } \\
\text { septic shock }\end{array}$ & $\begin{array}{l}\text { 10/20 patients }(50 \%) \text { had } \\
\text { depressed LVEF }(<0.40) \text {. Mean } \\
\text { LVEF was lower among } \\
\text { survivors (LVEF } 0.32 \pm 0.04) \\
\text { when compared to } \\
\text { non-survivors. Mean ESV and } \\
\text { EDV were increased in } \\
\text { survivors }\end{array}$ \\
\hline & GLS & $\begin{array}{l}\text { Boissier et al. } \\
\text { (2017) [17] }\end{array}$ & $\begin{array}{l}\text { Single-center } \\
\text { prospective cohort } \\
\text { study/ICU }\end{array}$ & 132 & $\begin{array}{l}\text { To evaluate the role of GLS, LVEF, } \\
\text { and TDI in patients with septic } \\
\text { shock. Primary outcome was the } \\
\text { role of loading conditions on } \\
\text { evaluation of cardiac contractility }\end{array}$ & $\begin{array}{l}\text { GLS was impaired in a majority } \\
\text { of the patients }(>70 \%) \text {; } \\
\text { however, feasibility was limited } \\
(<50 \%)\end{array}$ \\
\hline & & $\begin{array}{l}\text { Chang et al. } \\
\text { (2015) [39] }\end{array}$ & $\begin{array}{l}\text { Multi-center } \\
\text { prospective cohort } \\
\text { study/ICU }\end{array}$ & 111 & $\begin{array}{l}\text { To evaluate LV function, as well } \\
\text { as the prognostic value of GLS, in } \\
\text { septic patients. Primary outcome } \\
\text { was both ICU and hospital } \\
\text { mortality }\end{array}$ & $\begin{array}{l}\text { GLS is an independent } \\
\text { prognostic indicator of ICU } \\
\text { mortality. Patients with } \\
\text { GLS } \geq-13 \% \text { had higher ICU } \\
\text { mortality rates (HR 4.34; } \\
p<0.001 \text { ) }\end{array}$ \\
\hline & & $\begin{array}{l}\text { De Geer et al. } \\
\text { (2015) [43] }\end{array}$ & $\begin{array}{l}\text { Single-center } \\
\text { prospective cohort } \\
\text { study/ICU }\end{array}$ & 50 & $\begin{array}{l}\text { To evaluate GLS in patients with } \\
\text { septic shock. Primary outcomes } \\
\text { were mortality at } 30 \text { and } 90 \text { days }\end{array}$ & $\begin{array}{l}\text { GLPS did not correlate } \\
\text { between survivors and } \\
\text { non-survivors and therefore } \\
\text { could not be used to predict } \\
\text { mortality }\end{array}$ \\
\hline & & $\begin{array}{l}\text { Innocenti et al. } \\
\text { (2016) [41] }\end{array}$ & $\begin{array}{l}\text { Single-center } \\
\text { prospective cohort } \\
\text { study/ED } \\
\text { observation unit }\end{array}$ & 147 & $\begin{array}{l}\text { To evaluate LVEF and GLS in } \\
\text { septic patients. Primary outcome } \\
\text { was all-cause mortality at } 7 \text { days }\end{array}$ & $\begin{array}{l}\text { LVEF is not an independent } \\
\text { indicator of prognosis }\end{array}$ \\
\hline & & $\begin{array}{l}\text { Kalam et al. } \\
\text { (2014) [37] }\end{array}$ & Meta-analysis & 5721 & $\begin{array}{l}\text { To assess if GLS is a more } \\
\text { accurate predictor of } \\
\text { cardiovascular outcome } \\
\text { compared to LVEF. Primary } \\
\text { outcome was all-cause mortality. } \\
\text { Secondary outcome was } \\
\text { composite endpoint including } \\
\text { cardiac death, malignant } \\
\text { arrhythmia, and hospitalization }\end{array}$ & $\begin{array}{l}\text { GLS is a better predictor of } \\
\text { adverse outcomes (HR 0.50; } \\
p<0.002 \text { ) and mortality } \\
\text { (HR 1.62; } p=0.009 \text { ) than LVEF } \\
\text { (HR } 0.81 ; p=0.572)\end{array}$ \\
\hline & & $\begin{array}{l}\mathrm{Ng} \text { et al. } \\
\text { (2016) [38] }\end{array}$ & $\begin{array}{l}\text { Case-control study/ } \\
\text { ICU }\end{array}$ & 62 & $\begin{array}{l}\text { To evaluate the role of GLS in the } \\
\text { diagnosis of SMD. Primary } \\
\text { outcome was to compare GLS } \\
\text { values in patients with septic } \\
\text { shock compared to patients with } \\
\text { only sepsis }\end{array}$ & $\begin{array}{l}\text { There was a significant } \\
\text { difference in GLS values } \\
(-14.5 \text { vs }-18.3 \%, p<0.001) \\
\text { between patients with septic } \\
\text { shock and sepsis. LVEF was } \\
\text { not statistically significant } \\
\text { between patients with septic } \\
\text { shock and patients with sepsis }\end{array}$ \\
\hline
\end{tabular}


Table 2 Summary of selected articles on septic cardiomyopathy (Continued)

\begin{tabular}{|c|c|c|c|c|c|}
\hline $\begin{array}{l}\text { Echo } \\
\text { parameter }\end{array}$ & Study & $\begin{array}{l}\text { Study design/ } \\
\text { setting }\end{array}$ & $N$ & Measured outcome & Results \\
\hline & $\begin{array}{l}\text { Orde et al. } \\
\text { (2014) [42] }\end{array}$ & $\begin{array}{l}\text { Single-center } \\
\text { prospective cohort } \\
\text { study/ICU }\end{array}$ & 60 & $\begin{array}{l}\text { To evaluate GLS in patients with } \\
\text { severe sepsis or septic shock. } \\
\text { Primary outcomes were mortality } \\
\text { at } 30 \text { days and } 6 \text { months }\end{array}$ & $\begin{array}{l}\text { No difference in mortality for } \\
\text { LV GLS or GLS rate in survivors } \\
\text { compared with non-survivors } \\
\text { at } 30 \text { days or } 6 \text { months }\end{array}$ \\
\hline & $\begin{array}{l}\text { Palmieri et al. } \\
\text { (2015) [40] }\end{array}$ & $\begin{array}{l}\text { Single-center } \\
\text { prospective cohort } \\
\text { study/ED } \\
\text { observation unit }\end{array}$ & 115 & $\begin{array}{l}\text { To evaluate LV EF and peak GLS } \\
\text { in patients with sepsis and septic } \\
\text { shock. Primary outcome was } \\
\text { death by any cause at } 28 \text { days } \\
\text { from hospitalization }\end{array}$ & $\begin{array}{l}\text { Abnormal GLS correlates } \\
\text { significantly with mortality rate } \\
\text { at } 28 \text { days. GLS values close to } \\
0 \text { demonstrated a higher } \\
\text { mortality (HR } 1.16 \% ; p=0.05 \text { ). }\end{array}$ \\
\hline & $\begin{array}{l}\text { Zaky et al. } \\
\text { (2016) [44] }\end{array}$ & $\begin{array}{l}\text { Single-center } \\
\text { prospective cohort } \\
\text { study/ICU }\end{array}$ & 54 & $\begin{array}{l}\text { To evaluate LVLS in patients with } \\
\text { sepsis or septic shock. Primary } \\
\text { outcomes were mechanical } \\
\text { ventilation, ICU and hospital } \\
\text { length of stay, and in-hospital } \\
\text { mortality }\end{array}$ & $\begin{array}{l}\text { Global LVLS was not } \\
\text { associated with rates of } \\
\text { mechanical ventilation, ICU or } \\
\text { hospital length of stay, or } \\
\text { in-hospital mortality }\end{array}$ \\
\hline $\begin{array}{l}\text { Systolic } \\
\text { mitral } \\
\text { annular } \\
\text { velocity } \\
\left(S^{\prime}\right)\end{array}$ & $\begin{array}{l}\text { Chang et al. } \\
\text { (2015) [39] }\end{array}$ & $\begin{array}{l}\text { Multi-center } \\
\text { prospective cohort } \\
\text { study/ICU }\end{array}$ & 111 & $\begin{array}{l}\text { To evaluate LV function, as well } \\
\text { as the prognostic value of GLS, in } \\
\text { septic patients. Primary outcome } \\
\text { was both ICU and hospital } \\
\text { mortality }\end{array}$ & $\begin{array}{l}\text { There was no statistically } \\
\text { significant difference in } S^{\prime} \\
\text { between ICU non-survivors } \\
\text { compared to survivors } \\
(11.0 \pm 4.3 \text { vs } 11.4 \pm 4.0 ; \\
p<0.66)\end{array}$ \\
\hline
\end{tabular}

Weng et al. $\quad$ Single-center $\quad 61 \quad$ To evaluate the prognostic (2012) [49] prospective cohort study/ICU

Weng et al. (2013) [50]

MAPSE

Zhang et al. (2017) [65]

MPI

Nizamuddin et al. (2017) [78]

Diastolic $e^{\prime}$ and
E/e'

Brown et al. (2012) [52]

Landesberg et al. (2012) [54]
Single-center prospective cohort study/ICU

Case-control study/ ICU

Single-center prospective cohort study/ICU

Single-center prospective cohort study/ICU

Single-center prospective cohort study/ICU significance of several TDI variables, including systolic mitral annular velocity, $S^{\prime}$, in patients with septic shock. Primary outcome was all-cause mortality

51 To evaluate LV longitudinal systolic dysfunction and LV intraventricular systolic asynchrony assessed by TDI in patients with septic shock and normal LVEF. Primary outcome was all-cause mortality at 28 days

45 To evaluate LVEF, MAPSE, Sa, and TAPSE in patients with septic shock. Primary outcome was sepsis

47

To assess if changes in LV MPI were associated with higher 90-day mortality in patients with severe sepsis. Primary outcome was all-cause mortality

78 To evaluate whether severity of diastolic dysfunction predicts mortality in patients with severe sepsis or septic shock. Primary outcome was mortality at 28 days

262 To evaluate the association between diastolic dysfunction and mortality in severe sepsis and septic shock. Primary outcomes were in-hospital mortality and overall mortality at 6 months to 2 years
Non-survivors had a higher $S^{\prime}$ when compared to survivors (11.0 vs $7.8 \mathrm{~cm} / \mathrm{s} ; p<0.0001)$. Patients with $S^{\prime}>9 \mathrm{~cm} / \mathrm{s}$ had a higher mortality rate $(75$ versus 17\%; $p<0.0001)$. $S^{\prime}>9 \mathrm{~cm} / \mathrm{s}$ had SN 75\% and SP 86\% to predict 90-day mortality

Normal EF, LV longitudinal systolic dysfunction and LV systolic asynchrony assessed by TDI within $24 \mathrm{~h}$ of onset of septic shock were associated with improved mortality at 28 days

MAPSE values were significantly lower in septic patients when compared to non-septic patients $(p \leq 0.001)$

Decline in MPI over the initial 24-h study period was associated with higher mortality at 90 days $(p=0.04)$

Grade I diastolic dysfunction was associated with increased mortality; grades II/III were not associated with increased mortality

Decreased septal e' or increased septal E/e' were the strongest independent predictors of mortality (HR 0.76, $p \leq 0.001$ and HR $1.08, p \leq 0.001$, respectively) 
Table 2 Summary of selected articles on septic cardiomyopathy (Continued)

\begin{tabular}{|c|c|c|c|c|c|c|}
\hline & $\begin{array}{l}\text { Echo } \\
\text { parameter }\end{array}$ & Study & $\begin{array}{l}\text { Study design/ } \\
\text { setting }\end{array}$ & $N$ & Measured outcome & Results \\
\hline & & $\begin{array}{l}\text { Rolando et al. } \\
\text { (2015) [57] }\end{array}$ & $\begin{array}{l}\text { Single-center } \\
\text { prospective cohort } \\
\text { study/ICU }\end{array}$ & 53 & $\begin{array}{l}\text { To evaluate the prognostic } \\
\text { significance of myocardial } \\
\text { dysfunction, including E/e' ratio, } \\
\text { in patients with severe sepsis and } \\
\text { septic shock. Primary outcome } \\
\text { was hospital mortality }\end{array}$ & $\begin{array}{l}\text { E/e' is an independent } \\
\text { predictor of hospitality } \\
\text { mortality }(\mathrm{OR}=1.36 ; p=0.02) \text {. } \\
\text { An } E / \mathrm{e}^{\prime}>11 \text { had a sensitivity } \\
\text { of } 50 \% \text { and specificity of } 94 \% \\
\text { for predicting ICU mortality }\end{array}$ \\
\hline & & $\begin{array}{l}\text { Sanfilippo et al. } \\
\text { (2017) [59] }\end{array}$ & Meta-analysis & 1507 & $\begin{array}{l}\text { To evaluate the association of } e^{\prime} \\
\text { and E/e' with mortality in patients } \\
\text { with severe sepsis or septic shock }\end{array}$ & $\begin{array}{l}\text { A significant association was } \\
\text { found between mortality and } \\
\text { both a lower } \mathrm{e}^{\prime}(\mathrm{SC} 0.33 ; 95 \% \\
\mathrm{Cl} 0.05,0.62 ; p=0.02) \text { and } \\
\text { higher } \mathrm{E} / \mathrm{e}^{\prime}(\mathrm{SC} 0.33 ; 95 \% \\
\mathrm{Cl}-0.57,-0.10 ; p=0.006) \text { in } \\
\text { patients with severe sepsis } \\
\text { and/or septic shock. There was } \\
\text { high overall heterogeneity in } \\
\text { both } \mathrm{e}^{\prime} \text { and E/e' analysis }\end{array}$ \\
\hline & & $\begin{array}{l}\text { Sturgess et al. } \\
\text { (2010) [56] }\end{array}$ & $\begin{array}{l}\text { Single-center } \\
\text { prospective cohort } \\
\text { study/ICU }\end{array}$ & 21 & $\begin{array}{l}\text { To evaluate the prognostic } \\
\text { significance of TDI and cardiac } \\
\text { biomarkers in septic shock. } \\
\text { Primary outcome was hospital } \\
\text { mortality }\end{array}$ & $\begin{array}{l}\text { E/e' is an independent } \\
\text { predictor of hospital survival } \\
\text { and is a better prognosticator } \\
\text { than cardiac biomarkers. E/e' } \\
\text { was greater in non-survivors } \\
\text { than survivors ( } 15.32 \pm 2.74 \text { vs } \\
9.05 \pm 2.75 \text {, respectively; } \\
p=0.0002)\end{array}$ \\
\hline & & $\begin{array}{l}\text { Lanspa et al. } \\
\text { (2016) [60] }\end{array}$ & $\begin{array}{l}\text { Single-center } \\
\text { prospective cohort } \\
\text { study/ICU }\end{array}$ & 167 & $\begin{array}{l}\text { To compare the feasibility and } \\
\text { prognostic significance of a } \\
\text { simplified definition of diastolic } \\
\text { dysfunction (using } e^{\prime} \text { and E/e') } \\
\text { with } 2009 \text { ASE guidelines. Primary } \\
\text { outcome was 28-day mortality }\end{array}$ & $\begin{array}{l}\text { Simplified definition had } \\
\text { better feasibility ( } 87 \text { vs 35\%); } \\
\text { similar clinical outcomes } \\
\text { between groups suggesting } \\
\text { limited utility of LAVI and DT } \\
\text { in this setting }\end{array}$ \\
\hline \multicolumn{7}{|l|}{$\begin{array}{l}\text { Right } \\
\text { ventricle }\end{array}$} \\
\hline \multirow[t]{2}{*}{ Systolic } & TAPSE & $\begin{array}{l}\text { Gajanana et al. } \\
\text { (2015) [64] }\end{array}$ & $\begin{array}{l}\text { Single-center } \\
\text { prospective cohort } \\
\text { study/ICU }\end{array}$ & 120 & $\begin{array}{l}\text { To evaluate the prognostic value } \\
\text { of TAPSE in patients with critical } \\
\text { illness }\end{array}$ & $\begin{array}{l}\text { A reduced TAPSE } \\
\text { measurement }(<2.4 \mathrm{~cm}) \text { was } \\
\text { correlated with increased } \\
\text { in-hospital mortality }(x(2)=4.6 \text {, } \\
P=0.03) \text { and a longer length } \\
\text { of hospital stay }\end{array}$ \\
\hline & $\begin{array}{l}\text { TAPSE } \\
\text { TDI } \\
\text { RV FAC }\end{array}$ & $\begin{array}{l}\text { Vallabhajosyula } \\
\text { et al. (2017) } \\
\text { [67] }\end{array}$ & $\begin{array}{l}\text { Single-center } \\
\text { retrospective cohort } \\
\text { study/ICU }\end{array}$ & 388 & $\begin{array}{l}\text { To evaluate the prognostic } \\
\text { significance RV dysfunction in } \\
\text { patients with severe sepsis and } \\
\text { septic shock. Primary outcome } \\
\text { was 1-year survival }\end{array}$ & $\begin{array}{l}\text { Isolated RV dysfunction is an } \\
\text { independent predictor of } \\
1 \text {-year survival (HR 1.6; } \\
p=0.002 \text { ). Combined RV/LV } \\
\text { dysfunction was not an } \\
\text { independent predictor of } \\
\text { 1-year survival (HR 0.9; } \\
p=0.52 \text { ) }\end{array}$ \\
\hline
\end{tabular}

ASE American Society of Echocardiography, Cl confidence interval, DT mitral inflow deceleration time, EDV end diastolic volume, ESV end systolic volume, FAC fractional area change, GLPS global longitudinal peak strain, GLS global longitudinal strain, HR hazard ratio, ICU intensive care unit, $L A V I$ left atrial volume index, $L V$ left ventricle, $L V E F$ left ventricular ejection fraction, $L V L S$ left ventricular longitudinal strain, MAPSE mitral annular plane systolic excursion, OR odds ratio, RV right ventricle, Sa tissue Doppler velocity measurement of mitral annulus, SC septic cardiomyopathy, SMD standard mean difference, SN sensitivity, SP specificity, STE speckle tracking echocardiography, TDI tissue Doppler imaging

diseases [37]. $\mathrm{Ng}$ et al. [38] found that patients with septic shock had more LV dysfunction, as measured by GLS, than matched controls with sepsis but without shock. Chang et al. [39] prospectively enrolled 111 ICU patients with septic shock. LVEF was similar between in-hospital survivors and non-survivors, but GLS was significantly better in survivors compared to non-survivors, with an even greater difference for ICU mortality [39]. Palmieri et al. [40] reported similar findings. When dichotomized to "normal" (< $-14 \%)$ or "abnormal", Innocenti et al. [41] reported lower mortality at 7 and 28 days for those with normalized GLS.

Conversely, Orde et al. [42] found that although a greater number of patients had LV dysfunction identified by STE than LVEF (69 versus 33\%), there was no difference in GLS between survivors and non-survivors at 30 days or 6 months; De Geer et al. [43] also found no difference or improvement in GLS between survivors 
Table 3 Gaps and general limitations of the septic cardiomyopathy literature

\begin{tabular}{|c|c|c|}
\hline & Limitations & Potential Impact \\
\hline \multirow[t]{5}{*}{ Patient-related factors } & $\begin{array}{l}\text { Observational study designs with generally small } \\
\text { sample sizes }\end{array}$ & $\begin{array}{l}\text { High degree of confounding and bias; elucidation of true } \\
\text { causal relationships not possible }\end{array}$ \\
\hline & $\begin{array}{l}\text { Heterogeneous sepsis classification (SOFA, SIRS) } \\
\text { and severity }\end{array}$ & $\begin{array}{l}\text { Difficult to make conclusions across varied populations; } \\
\text { prognostic value of echocardiography findings confounded } \\
\text { by collinearity between severity of disease and adverse } \\
\text { outcomes }\end{array}$ \\
\hline & Pre-septic cardiac function largely unknown & $\begin{array}{l}\text { Acute versus chronic dysfunction may portend different } \\
\text { prognosis }\end{array}$ \\
\hline & Variation in co-morbidities & $\begin{array}{l}\text { Complex interaction between pre-existing illnesses, acute } \\
\text { infection, and treatment renders cross-patient comparisons } \\
\text { difficult }\end{array}$ \\
\hline & $\begin{array}{l}\text { Variation in treatments (mechanical ventilation, } \\
\text { vasopressors, inotropes) }\end{array}$ & $\begin{array}{l}\text { Therapeutic interventions likely affect cardiac performance } \\
\text { and echocardiographic measurements and may alter } \\
\text { outcomes }\end{array}$ \\
\hline \multirow[t]{4}{*}{$\begin{array}{l}\text { Echocardiography-related } \\
\text { factors }\end{array}$} & Variable timing of initial echocardiogram & $\begin{array}{l}\text { Normal progression of disease (natural history) and } \\
\text { treatment prior to initial exam may alter findings }\end{array}$ \\
\hline & $\begin{array}{l}\text { Variability of timing and number of repeat } \\
\text { echocardiograms }\end{array}$ & $\begin{array}{l}\text { Ongoing resuscitation may alter cardiac performance via } \\
\text { intrinsic (e.g., increased contractility) or extrinsic (change in } \\
\text { loading conditions) factors }\end{array}$ \\
\hline & Reference ranges derived in stable patients & $\begin{array}{l}\text { Unknown how/if normal values are applicable in the setting } \\
\text { of sepsis }\end{array}$ \\
\hline & $\begin{array}{l}\text { GLS values not standardized across ultrasound } \\
\text { vendors }\end{array}$ & Difficult to compare GLS values across US systems \\
\hline
\end{tabular}

GLS global longitudinal strain, SIRS systemic inflammatory response syndrome, SOFA Sequential Organ Failure Assessment, US ultrasound

and non-survivors at 30 and 90 days. Finally, Zaky et al. [44] reported similar strain values in survivors and nonsurvivors; however, apical segments were excluded from their strain analysis, making interpretation of these results somewhat difficult. In terms of feasibility of performing STE in septic patients, studies have reported exclusion rates for poor image quality from $1.5-20 \%[40-43,45,46]$. De Geer et al. [46] found GLS to be the most reproducible measure for assessing cardiac function in patients with septic shock, with intraclass correlation coefficients for interand intraobserver variability of $0.91(0.74-0.95, p<0.001)$, and $0.89(0.55-0.97, p=0.002)$, respectively.

\section{Other considerations}

Systolic function can also be assessed using tissue Doppler imaging (TDI)-derived velocity of the mitral annulus or by mitral annular plane systolic excursion (MAPSE). Peak systolic velocity of the mitral annulus, denoted $S^{\prime}$, has been shown to have prognostic value in a variety of cardiovascular illnesses [47] and is relatively afterload-independent [17]. MAPSE is the linear distance the mitral annulus moves towards the LV apex during systole and has demonstrated similar utility [48].

The evidence with regard to the utility of these variables in septic patients is conflicting. Weng et al. [49] found a linear correlation between $S^{\prime}$ and LVEF in septic shock, and that non-survivors had higher $\mathrm{S}^{\prime}$ than survivors; Boissier et al. [17] reported similar findings. A study of septic patients with LVEF > 50\% also noted lower $\mathrm{S}^{\prime}$ in survivors compared to non-survivors [50]. Conversely, Chang et al. [39] found no association between $\mathrm{S}^{\prime}$ and ICU or in-hospital mortality.

\section{Left ventricle: diastolic function}

In the absence of infiltrative or restrictive cardiac disease, diastole is the main determinant of LV compliance [51]. While initially low in SC, regardless of systolic function, as diastolic function worsens, left ventricular end-diastolic pressure (LVEDP) can rise. Preload augmentation, via increased left ventricular end-diastolic volume, can lead to further elevation in LVEDP-Brown et al. [52] found that diastolic dysfunction (DD) was more common in patients administered larger volumes of IVF. Mahjoub et al. [53] reported less increase in LVEDP in volume-responsive septic patients than in non-responders, demonstrating the varied effects of IVF-loading, depending on underlying cardiac function. A putative explanation of the detrimental effects of DD in sepsis is that elevated left-sided pressure increases pressure in the pulmonary circulation, the right heart, and the peripheral tissues, which leads to increases in extravascular lung water (EVLW) and tissue edema.

The preferred method for evaluation of diastolic function is TDI-derived velocity of the mitral annuls during early diastole $\left(e^{\prime}\right)$, with lower values corresponding to worse diastolic function [51]. The ratio of the peak trans-mitral 

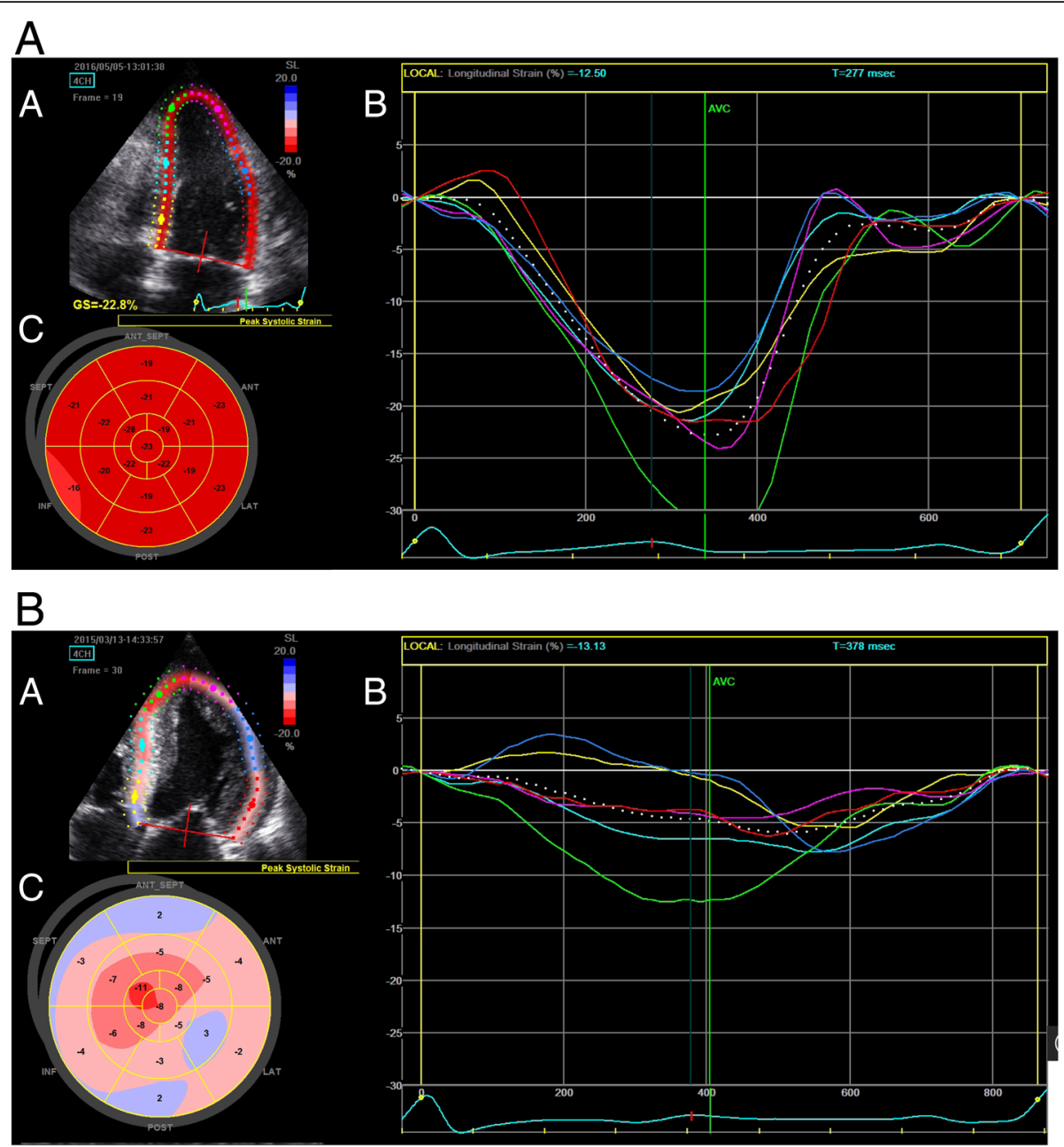

Fig. 2 a Speckle-tracking analysis of a patient with normal systolic left ventricular (LV) function. 2D image showing speckles within the LV being tracked by the ultrasound Machine Software (A). Graphical representation of movement of speckles throughout the cardiac cycle ( $\mathrm{x}$-axis, longitudinal strain; $y$-axis, time in $\mathrm{msec}$ ), with each line representing a different segment of the LV; large negative values represent movement of speckles towards one another during contraction representing normal function (B). Bullseye map showing global longitudinal strain values throughout the LV (C). b Speckle-tracking analysis of a patient with severely reduced left ventricular (LV) systolic function. A 2D image showing speckles within the LV being tracked by the ultrasound machine software (A). Graphical representation of movement of speckles throughout the cardiac cycle ( $x$-axis, longitudinal strain; $y$-axis, time in $\mathrm{msec}$ ) with each line representing a different segment of the LV; note smaller negative values with variable time to peak strain representing reduced LV function with mechanical dyssynchrony (B). Bullseye map showing global longitudinal strain values throughout the $L V ;$ blue zones represent areas of the LV where there is lengthening of the segments during systole rather than shortening (C)

inflow velocity in early diastole $(E)$ to early diastolic mitral annular velocity $\left(E / e^{\prime}\right)$ has been found to correlate with leftatrial pressure-a surrogate for pulmonary capillary wedge pressure [51]; higher values reflect increased pressure.

Prognostic ability of $E / e^{\prime}$ and $e^{\prime}$ have been evaluated in septic patients, with conflicting results. Three studies reported lower e' in non-survivors compared to survivors [54-56]; two others found that elevated E/e' was an independent predictor of in-hospital mortality [56, 57]. A 2015 meta-analysis [58] of 636 patients found a prevalence of DD of $20-57 \%$ and a relative risk of death of 1.82 (1.12-2.97, $\left.p=0.002 ; \mathrm{I}^{2}=77 \%\right)$. A 2017 update [59], of 1507 patients, found lower lateral e' and higher E/e' amongst non-survivors. Interestingly, Brown et al. [52] found increased mortality only for patients with low-grade DD (impaired relaxation with minimally elevated LVEDP); however, these patients received significantly less fluid than those with more severe DD-2.6 versus $5.5 \mathrm{l}$-prior to the initial echocardiogram and thus they may have been inadequately resuscitated. While e' is considered to be relatively preload independent [51], this latter finding suggests there is a link between fluid loading and derangement in diastolic function. In contrast, several other studies failed to detect an association between DD and mortality (early or late-up to 1 year) in severe sepsis and septic shock [30, 31, 39, 43, 49]. 
Lanspa et al. [60] found better feasibility of a simplified diastolic evaluation compared to the 2009 American Society for Echocardiography (ASE) guidelines, without loss of predictive value (see Tables 1 and 2 for further details).

\section{Right ventricle}

Dysfunction of the right ventricle (RV) contributes to morbidity and mortality in a variety of conditions, including heart failure and pulmonary hypertension [61, 62]. Tricuspid annular plane systolic excursion (TAPSE) is the easiest and most reproducible measure of RV function [63]. Reduced TAPSE has been correlated with increased mortality in critical illness [64] and detected in septic ICU patients when compared to non-septic ICU controls $[38,65]$. Whether RV dysfunction is a manifestation of disease severity-and thus associated with poor outcomes-or a causative factor of morbidity and mortality is unknown. Contributors to RV dysfunction include LV dysfunction, hypoxia, hypercarbia, mechanical ventilation with high positive end-expiratory pressure, atelectasis, and fluid overload [42, 62]. Pulmonary hypertension induced (or exacerbated by) acute respiratory distress syndrome or pulmonary sources of sepsis can also contribute to RV dysfunction; isolated RV dysfunction may be more common in patients with these conditions compared to those without.

Reported prevalence of RV dysfunction in sepsis varies, from 31 to $83 \%$ [31, 57]. As with other echocardiographic variables, investigation of RV parameters has produced conflicting results. Traditional parameters of increased RV size and dysfunction have been associated with increased mortality in some studies $[55,66]$, but not others [31, 39, 54, 57]. A retrospective study of 388 septic ICU patients [67] found isolated RV dysfunction to be an independent predictor of 1-year mortality; combined RV/LV dysfunction showed no such relationship. A meta-analysis of 412 patients found no association between RV function and mortality [32]. Orde et al. [42] reported that reduced RV free wall strain (by STE) was associated with 6 -month mortality $(-16.0 \pm 5.7$ versus $-19.3 \pm 4.9, p \leq 0.05)$; these results are promising but require validation.

\section{Biomarkers}

Abnormal cardiac biomarkers, primarily troponin and natriuretic peptides (NPs), are another potential indicator of myocardial dysfunction that provide unique but related information about the heart [10]. Troponin elevation in the setting of sepsis may reflect altered cardiomyocyte permeability or necrosis from vascular injury rather than atherosclerotic disease [68], but determining whether it is related to $\mathrm{SC}$ or another condition (e.g., renal disease) is difficult.
Contemporary troponin assays (cTnI, cTnT) have been studied in septic patients, with concentrations generally rising with increasing disease severity; shortterm non-survivors often have greater elevations than survivors [10,69], but the results are not uniform [70]. Vallabhajosysula et al. [71] reported that, in septic ICU patients, elevated TnT on admission was associated with higher in-hospital and 1-year mortality compared to patients whose TnT was not elevated; no such associations were found for elevated $\Delta \mathrm{TnT}$. High-sensitivity troponin (hsTnT) has also been reported to rise with increasing severity of sepsis, but with unclear prognostic implications: Rosjo et al. [70] reported greater hsTnT elevation in non-survivors, but no independent association with mortality; Masson et al. [72] found that an elevated hsTnT on day 7 (but not day 1) and a $>20 \%$ rise from day 1 to day 2 were associated with increased mortality.

B-type NP (BNP), which is released in response to wall stress, reflects myocardial loading conditions and provides indirect functional information-as the heart moves towards the unfavorable portion of the Frank-Starling curve, wall stress, and BNP, rise [73, 74]. As with BNP, aminoterminal pro-BNP (NT-proBNP) may be elevated in sepsis, particularly with increasing disease severity, and is more likely to be elevated in non-survivors compared to survivors $[69,72-75]$. In one study, NT-proBNP was a better predictor of 90-day mortality than hsTnT [72]. Concomitant study of biomarkers and echocardiographic variables has not produced reliable results. No associations have been found between LV systolic function and contemporary troponin assays [31, 44]; one study reported an inverse relationship between LVEF and hsTnT [54], another found a weak association between hsTnT and declining GLS $(r=0.35)$ [43], and a third found no relationship [55]. Dilation of the RV and LV DD have been variably associated, with direct correlations for cTnT, hsTnT, and NT-proBNP in some studies [54, 55, 76], but not in others [31]. Sturgess et al. [56] found that E/e' $>15$ was a better predictor of in-hospital mortality than TnT or NTproBNP.

Some of this variability may be due to the fact that cardiac biomarker concentrations above the reference range are common in sepsis, with prevalence as high as $84 \%$ for cTnT [77], 98\% for NT-proBNP [75], and $100 \%$ for hsTnT [70]. Existing data are limited by residual confounding from clinical contributors, including age, disease severity, comorbidities (including flow-limiting $\mathrm{CAD}$ ), and treatment. Pending future studies, existing information on cardiac biomarkers can be summarized by noting that abnormalities in the setting of sepsis are likely, but such abnormalities, in and of themselves, do not equate to a diagnosis of $\mathrm{SC}$, nor do they provide clear, independent prognostic information. 


\section{Implications for treatment}

Currently, no treatment recommendations exist that specifically address the presence of SC. Patients with SC may be at greater risk for excessive fluid resuscitation and more likely to require inotropic support, as hypoperfusion would less likely be corrected by IVF administration alone. However, data comparing use of vasopressors, inotropes, and other treatments in patients with and without SC are scant and subject to extensive confounding. Where treatment data are stratified by presence or absence of SC [31, 44, 52, 78], only two found significant differences between groups. Brown et al. [52] found that patients with less severe DD received less IVF than those with more significant abnormalities (2.6 versus 5.5 l). Pulido et al. [31] reported higher doses of noradrenaline (norepinephrine) in patients with LV and RV systolic dysfunction, but no overall difference in the number of patients receiving it. Establishment of a standardized, objective definition of SC and adoption of more uniform study protocols amongst research groups would improve understanding of differences in treatment requirements for patients with SC.

Positive inotropic agents have the same putative benefits of vasopressors-increasing $\mathrm{CO}$, thereby improving oxygen delivery to the peripheral tissues. Recommendations to titrate therapy to central venous oxygen saturation $>65 \%$ are of uncertain utility, as a normal value does not necessarily indicate adequate resuscitation [79]. Furthermore, excessive $\beta$ stimulation may be harmful, and there is some evidence that $\beta$-blockade may be beneficial in some patients [80]. Preliminary trials of levosimendan, a calcium sensitizer and positive inotrope, reported reduced mortality [81], but no benefit was found in a subsequent larger study [82].

\section{Conclusions}

$\mathrm{SC}$ is a multi-factorial process that involves complex interactions between host and pathogen factors, and a full understanding of the disease process remains elusive. Prognostic implications of echocardiographic and biomarker findings are precluded by conflicting data from extant literature. Formal diagnostic criteria for SC do not exist; development of these, and studies based thereon, should be priorities for future research.

\footnotetext{
Abbreviations

ASE: American society of echocardiography; BNP: B-type natriuretic peptide: CAD: Coronary artery disease; Cl: Confidence interval; $\mathrm{CO}$ : Cardiac output; CTnT/CTnl: Contemporary troponin T/l; CVP: Central venous pressure; DT: Mitral inflow deceleration time; EDV: End diastolic volume; ESV: End systolic volume; GLPS: Global longitudinal peak strain; GLS: Global longitudinal strain; HR: Hazard ratio; hsTnT: High-sensitivity troponin T; ICU: Intensive care unit; IVC: Inferior vena cava; LAVI: Left atrial volume index; LV: Left ventricle; LVEF: Left ventricular ejection fraction; MAPSE: Mitral annular plane systolic excursion; msec: Millisecond; NP: Natriuretic peptide; NT pro-BNP: Amino-terminal pro-BNP; OR: Odds ratio; Sa: Tissue doppler velocity measurement of mitral annulus; SC: Septic cardiomyopathy; SN: Sensitivity;
}

SP: Specificity; STE: Speckle tracking echocardiography; SVR: Systemic vascular resistance; TDI: Tissue doppler imaging

\section{Acknowledgements}

The authors would like to acknowledge Daniel Foley, BS for the creation of Fig. 1.

\section{Authors' contributions}

RE and PL conceived the article; AS created the tables; CR created the conceptual framework of Fig. 1 and provided basic science expertise for the pathophysiology section; all of the authors contributed substantially to drafting and revising the manuscript and have given final approval of the submitted draft; RE takes responsibility for the manuscript as a whole.

\section{Competing interests}

$\mathrm{PL}$ received consulting fees from the following companies/organizations: Novartis Pharmaceuticals, Cardiorentis Inc., Trevena Inc., Apex Innovations, Roche Diagnostics, Siemens, Shire, Sciex. PL received consulting fees from the following institutions/organizations: Novartis Pharmaceuticals, Cardiorentis Inc., Trevena Inc., Amgen, BMS, Edwards Lifesciences, AHRQ (1 R01 HS025411), NHLBI (1 R34 HL136986 and 5 R01 HL127215), NIH Admin (1 U24 NS100680), PCORI (FC14-1409-21,656), Blue Cross Blue Shield of MI Foundation. The other authors have no competing interests.

\section{Publisher's Note}

Springer Nature remains neutral with regard to jurisdictional claims in published maps and institutional affiliations.

\section{Author details}

${ }^{1}$ Department of Emergency Medicine, Wayne State University School of Medicine, Detroit Medical Center/Sinai-Grace Hospital, 4201 St. Antoine, Suite 3R, Detroit, MI 48201, USA. ²Department of Emergency Medicine, Wayne State University School of Medicine, St. John Hospital and Medical Center, 22101 Moross Rd, Detroit, MI 48236, USA. ${ }^{3}$ Department of Emergency Medicine, Cardiovascular Research Institute, Wayne State University School of Medicine, 540 E. Canfield, Detroit, Ml 48201, USA. Division of Cardiology, Wayne State University School of Medicine, John D. Dingell VA Medical Center, 3990 John R. 4 Hudson, Detroit, MI 48377, USA. ${ }^{5}$ Department of Emergency Medicine, Wayne State University School of Medicine, Detroit Medical Center/Detroit Receiving Hospital, 4201 St. Antoine, Suite 3R, Detroit, MI 48201, USA.

Received: 4 January 2018 Accepted: 16 April 2018

Published online: 04 May 2018

References

1. Parker MM, Shelhamer JH, Bacharach SL, Green MV, Natanson C, Frederick TM, Damske BA, Parrillo JE. Profound but reversible myocardial depression in patients with septic shock. Ann Intern Med. 1984;100(4):483-90.

2. Weisel RD, Vito L, Dennis RC, Valeri CR, Hechtman HB. Myocardial depression during sepsis. Am J Surg. 1977;133(4):512-21.

3. Charpentier J, Luyt CE, Fulla Y, Vinsonneau C, Cariou A, Grabar S, Dhainaut JF, Mira JP, Chiche JD. Brain natriuretic peptide: A marker of myocardial dysfunction and prognosis during severe sepsis. Crit Care Med. 2004;32(3):660-5.

4. Poelaert J, Declerck C, Vogelaers D, Colardyn F, Visser CA. Left ventricular systolic and diastolic function in septic shock. Intensive Care Med. 1997; 23(5):553-60.

5. Kakihana Y, Ito T, Nakahara M, Yamaguchi K, Yasuda T. Sepsis-induced myocardial dysfunction: pathophysiology and management. J Intensive Care. 2016:4:22.

6. Zanotti-Cavazzoni SL, Hollenberg SM. Cardiac dysfunction in severe sepsis and septic shock. Curr Opin Crit Care. 2009;15(5):392-7.

7. Murphy CV, Schramm GE, Doherty JA, Reichley RM, Gajic O, Afessa B, Micek $\mathrm{ST}$, Kollef $\mathrm{MH}$. The importance of fluid management in acute lung injury secondary to septic shock. Chest. 2009;136(1):102-9.

8. Wiedemann HP, Wheeler AP, Bernard GR, Thompson BT, Hayden D, deBoisblanc B, Connors AF Jr, Hite RD, Harabin AL. Comparison of two fluid-management strategies in acute lung injury. N Engl J Med. 2006; 354(24):2564-75. 
9. Schneider AJ, Teule GJ, Groeneveld AB, Nauta J, Heidendal GA, Thijs LG. Biventricular performance during volume loading in patients with early septic shock, with emphasis on the right ventricle: a combined hemodynamic and radionuclide study. Am Heart J. 1988;116(1 Pt 1):103-12.

10. Maeder M, Fehr T, Rickli H, Ammann P. Sepsis-associated myocardial dysfunction: diagnostic and prognostic impact of cardiac troponins and natriuretic peptides. Chest. 2006;129(5):1349-66.

11. Russell JA, Boyd J, Nakada T, Thair S, Walley KR. Molecular mechanisms of sepsis. Contrib Microbiol. 2011;17:48-85.

12. Conway-Morris A, Wilson J, Shankar-Hari M. Immune activation in sepsis. Crit Care Clin. 2018;34(1):29-42

13. Anthonymuthu TS, Kim-Campbell N, Bayir H. Oxidative lipidomics: applications in critical care. Curr Opin Crit Care. 2017;23(4):251-6.

14. Bednarczyk JM, Fridfinnson JA, Kumar A, Blanchard L, Rabbani R, Bell D, Funk D, Turgeon AF, Abou-Setta AM, Zarychanski R. Incorporating dynamic assessment of fluid responsiveness into goal-directed therapy: a systematic review and meta-analysis. Crit Care Med. 2017:45(9):1538-45.

15. Cherpanath TG, Hirsch A, Geerts BF, Lagrand WK, Leeflang MM, Schultz MJ, Groeneveld AB. Predicting fluid responsiveness by passive leg raising: a systematic review and meta-analysis of 23 clinical trials. Crit Care Med. 2016; 44(5):981-91.

16. Ma IWY, Caplin JD, Azad A, Wilson C, Fifer MA, Bagchi A, Liteplo AS, Noble VE. Correlation of carotid blood flow and corrected carotid flow time with invasive cardiac output measurements. Crit Ultrasound J. 2017;9(1):10.

17. Boissier F, Razazi K, Seemann A, Bedet A, Thille AW, de Prost N, Lim P, BrunBuisson C, Mekontso Dessap A. Left ventricular systolic dysfunction during septic shock: the role of loading conditions. Intensive Care Med. 2017;43(5):633-42.

18. Bruni FD, Komwatana P, Soulsby ME, Hess ML. Endotoxin and myocardial failure: role of the myofibril and venous return. Am J Phys. 1978:235(2):H150-6.

19. Cunnion RE, Schaer GL, Parker MM, Natanson C, Parrillo JE. The coronary circulation in human septic shock. Circulation. 1986;73(4):637-44.

20. Sato R, Nasu M. A review of sepsis-induced cardiomyopathy. J Intensive Care. 2015:3:48

21. Madorin WS, Rui T, Sugimoto N, Handa O, Cepinskas G, Kvietys PR. Cardiac myocytes activated by septic plasma promote neutrophil transendothelial migration: role of platelet-activating factor and the chemokines LIX and KC. Circ Res. 2004;94(7):944-51.

22. Rudiger A, Singer M. Mechanisms of sepsis-induced cardiac dysfunction. Crit Care Med. 2007:35(6):1599-608.

23. Celes MR, Torres-Duenas D, Malvestio LM, Blefari V, Campos EC, Ramos SG, Prado CM, Cunha FQ, Rossi MA. Disruption of sarcolemmal dystrophin and beta-dystroglycan may be a potential mechanism for myocardial dysfunction in severe sepsis. Lab Investig. 2010;90(4):531-42.

24. Jardin F, Fourme T, Page B, Loubieres Y, Vieillard-Baron A, Beauchet A Bourdarias JP. Persistent preload defect in severe sepsis despite fluid loading: A longitudinal echocardiographic study in patients with septic shock. Chest. 1999;116(5):1354-9.

25. Siddiqui Y, Crouser ED, Raman SV. Nonischemic myocardial changes detected by cardiac magnetic resonance in critical care patients with sepsis. Am J Respir Crit Care Med. 2013:188(8):1037-9.

26. Levy RJ, Piel DA, Acton PD, Zhou R, Ferrari VA, Karp JS, Deutschman CS. Evidence of myocardial hibernation in the septic heart. Crit Care Med. 2005; 33(12):2752-6.

27. Budinger GR, Duranteau J, Chandel NS, Schumacker PT. Hibernation during hypoxia in cardiomyocytes. Role of mitochondria as the $\mathrm{O} 2$ sensor. J Biol Chem. 1998;273(6):3320-6.

28. Cappelletti S, Ciallella C, Aromatario M, Ashrafian H, Harding S, Athanasiou T. Takotsubo Cardiomyopathy and Sepsis. Angiology. 2017;68(4):288-303.

29. Balshem $H$, Helfand M, Schunemann HJ, Oxman AD, Kunz R, Brozek J, Vist GE, Falck-Ytter Y, Meerpohl J, Norris S, et al. GRADE guidelines: 3. Rating the quality of evidence. J Clin Epidemiol. 2011;64(4):401-6.

30. McLean AS, Huang SJ, Hyams S, Poh G, Nalos M, Pandit R, Balik M, Tang B, Seppelt I. Prognostic values of B-type natriuretic peptide in severe sepsis and septic shock. Crit Care Med. 2007;35(4):1019-26.

31. Pulido JN, Afessa B, Masaki M, Yuasa T, Gillespie S, Herasevich V, Brown DR, Oh JK. Clinical spectrum, frequency, and significance of myocardial dysfunction in severe sepsis and septic shock. Mayo Clin Proc. 2012;87(7):620-8.

32. Huang SJ, Nalos M, McLean AS. Is early ventricular dysfunction or dilatation associated with lower mortality rate in adult severe sepsis and septic shock? A meta-analysis. Crit Care. 2013;17(3):R96.
33. Sevilla Berrios RA, O'Horo JC, Velagapudi V, Pulido JN. Correlation of left ventricular systolic dysfunction determined by low ejection fraction and 30-day mortality in patients with severe sepsis and septic shock: a systematic review and meta-analysis. J Crit Care. 2014;29(4):495-9.

34. Smiseth OA, Torp H, Opdahl A, Haugaa KH, Urheim S. Myocardial strain imaging: how useful is it in clinical decision making? Eur Heart J. 2016; 37(15):1196-207.

35. Kaluzynski K, Chen X, Emelianov SY, Skovoroda AR, O'Donnell M. Strain rate imaging using two-dimensional speckle tracking. IEEE Trans Ultrason Ferroelectr Freq Control. 2001;48(4):1111-23.

36. Basu S, Frank LH, Fenton KE, Sable CA, Levy RJ, Berger JT. Two-dimensional speckle tracking imaging detects impaired myocardial performance in children with septic shock, not recognized by conventional echocardiography. Pediatr Crit Care Med. 2012;13(3):259-64.

37. Kalam K, Otahal P, Marwick TH. Prognostic implications of global LV dysfunction: a systematic review and meta-analysis of global longitudinal strain and ejection fraction. Heart. 2014;100(21):1673-80.

38. Ng PY, Sin WC, Ng AK, Chan WM. Speckle tracking echocardiography in patients with septic shock: a case control study (SPECKSS). Crit Care. 2016;20(1):145.

39. Chang WT, Lee WH, Lee WT, Chen PS, Su YR, Liu PY, Liu YW, Tsai WC. Left ventricular global longitudinal strain is independently associated with mortality in septic shock patients. Intensive Care Med. 2015;41(10):1791-9.

40. Palmieri V, Innocenti F, Guzzo A, Guerrini E, Vignaroli D, Pini R. Left ventricular systolic longitudinal function as predictor of outcome in patients with sepsis. Circ Cardiovasc Imaging. 2015;8(11):e003865. discussion e003865

41. Innocenti F, Palmieri V, Guzzo A, Stefanone VT, Donnini C, Pini R. SOFA score and left ventricular systolic function as predictors of short-term outcome in patients with sepsis. Internal and emergency medicine. 2018; 13(1):51-58.

42. Orde SR, Pulido JN, Masaki M, Gillespie S, Spoon JN, Kane GC, Oh JK. Outcome prediction in sepsis: speckle tracking echocardiography based assessment of myocardial function. Crit Care. 2014;18(4):R149.

43. De Geer L, Engvall J, Oscarsson A. Strain echocardiography in septic shock - a comparison with systolic and diastolic function parameters, cardiac biomarkers and outcome. Crit Care. 2015:19:122.

44. Zaky A, Gill EA, Lin CP, Paul CP, Bendjelid K, Treggiari MM. Characteristics of sepsis-induced cardiac dysfunction using speckle-tracking echocardiography: a feasibility study. Anaesth Intensive Care. 2016;44(1):65-76.

45. Dalla K, Hallman C, Bech-Hanssen O, Haney M, Ricksten SE. Strain echocardiography identifies impaired longitudinal systolic function in patients with septic shock and preserved ejection fraction. Cardiovasc Ultrasound. 2015;13:30

46. De Geer L, Oscarsson A, Engvall J. Variability in echocardiographic measurements of left ventricular function in septic shock patients. Cardiovasc Ultrasound. 2015;13:19.

47. Yu CM, Sanderson JE, Marwick TH, Oh JK. Tissue Doppler imaging a new prognosticator for cardiovascular diseases. J Am Coll Cardiol. 2007; 49(19):1903-14.

48. Paraskevaidis IA, Kyrzopoulos S, Farmakis D, Parissis J, Tsiapras D, lliodromitis EK, Kremastinos DT. Ventricular long-axis contraction as an earlier predictor of outcome in asymptomatic aortic regurgitation. Am J Cardiol. 2007; 100(11):1677-82

49. Weng L, Liu YT, Du B, Zhou JF, Guo XX, Peng JM, Hu XY, Zhang SY, Fang $Q$, Zhu WL. The prognostic value of left ventricular systolic function measured by tissue Doppler imaging in septic shock. Crit Care. 2012;16(3):R71

50. Weng L, Liu Y, Zhou J, Guo X, Peng J, Hu X, Fang Q, Zhu W, Li H, Du B, et al. Left ventricular systolic function and systolic asynchrony in patients with septic shock and normal left ventricular ejection fraction. Shock (Augusta, GA). 2013;40(3):175-81.

51. Nagueh SF, Smiseth OA, Appleton CP, Byrd BF 3rd, Dokainish H, Edvardsen T, Flachskampf FA, Gillebert TC, Klein AL, Lancellotti P, et al. Recommendations for the evaluation of left ventricular diastolic function by echocardiography: an update from the American Society of Echocardiography and the European Association of Cardiovascular Imaging. Eur Heart J Cardiovasc Imaging. 2016;17(12):1321-60.

52. Brown SM, Pittman JE, Hirshberg EL, Jones JP, Lanspa MJ, Kuttler KG, Litwin SE, Grissom CK. Diastolic dysfunction and mortality in early severe sepsis and septic shock: a prospective, observational echocardiography study. Crit Ultrasound J. 2012;4(1):8 
53. Mahjoub Y, Benoit-Fallet H, Airapetian N, Lorne E, Levrard M, Seydi AA Amennouche N, Slama M, Dupont H. Improvement of left ventricular relaxation as assessed by tissue Doppler imaging in fluid-responsive critically ill septic patients. Intensive Care Med. 2012;38(9):1461-70.

54. Landesberg G, Gilon D, Meroz Y, Georgieva M, Levin PD, Goodman S, Avidan A, Beeri R, Weissman C, Jaffe AS, et al. Diastolic dysfunction and mortality in severe sepsis and septic shock. Eur Heart J. 2012;33(7):895-903.

55. Landesberg G, Jaffe AS, Gilon D, Levin PD, Goodman S, Abu-Baih A, Beeri R, Weissman C, Sprung CL, Landesberg A. Troponin elevation in severe sepsis and septic shock: the role of left ventricular diastolic dysfunction and right ventricular dilatation. Crit Care Med. 2014:42(4):790-800.

56. Sturgess DJ, Marwick TH, Joyce $C$, Jenkins $C$, Jones M, Masci P, Stewart D, Venkatesh B. Prediction of hospital outcome in septic shock: a prospective comparison of tissue Doppler and cardiac biomarkers. Crit Care. 2010;14(2):R44.

57. Rolando G, Espinoza ED, Avid E, Welsh S, Pozo JD, Vazquez AR, Arzani Y, Masevicius FD, Dubin A. Prognostic value of ventricular diastolic dysfunction in patients with severe sepsis and septic shock. Rev Bras Ter Intensiva. 2015; 27(4):333-9.

58. Sanfilippo F, Corredor C, Fletcher N, Landesberg G, Benedetto U, Foex P, Cecconi M. Diastolic dysfunction and mortality in septic patients: a systematic review and meta-analysis. Intensive Care Med. 2015;41(6):1004-13.

59. Sanfilippo F, Corredor C, Arcadipane A, Landesberg G, Vieillard-Baron A, Cecconi M, Fletcher N. Tissue Doppler assessment of diastolic function and relationship with mortality in critically ill septic patients: a systematic review and meta-analysis. Br J Anaesth. 2017;119(4):583-94.

60. Lanspa MJ, Gutsche AR, Wilson EL, Olsen TD, Hirshberg EL, Knox DB, Brown SM, Grissom CK. Application of a simplified definition of diastolic function in severe sepsis and septic shock. Crit Care. 2016;20(1):243.

61. Damy T, Ghio S, Rigby AS, Hittinger L, Jacobs S, Leyva F, Delgado JF, Daubert JC, Gras D, Tavazzi L, et al. Interplay between right ventricular function and cardiac resynchronization therapy: an analysis of the CARE-HF trial (Cardiac Resynchronization-Heart Failure). J Am Coll Cardiol. 2013;61(21):2153-60.

62. Forfia PR, Fisher MR, Mathai SC, Housten-Harris T, Hemnes AR, Borlaug BA, Chamera E, Corretti MC, Champion HC, Abraham TP, et al. Tricuspid annular displacement predicts survival in pulmonary hypertension. Am J Respir Crit Care Med. 2006:174(9):1034-41.

63. Lang RM, Badano LP, Mor-Avi V, Afilalo J, Armstrong A, Ernande L, Flachskampf FA, Foster E, Goldstein SA, Kuznetsova T, et al. Recommendations for cardiac chamber quantification by echocardiography in adults: an update from the American Society of Echocardiography and the European Association of Cardiovascular Imaging. Eur Heart J Cardiovasc Imaging. 2015;16(3):233-70.

64. Gajanana D, Seetha Rammohan H, Alli O, Romero-Corral A, Purushottam B, Ponamgi S, Figueredo VM, Pressman GS. Tricuspid annular plane systolic excursion and its association with mortality in critically ill patients. Echocardiography (Mount Kisco, NY). 2015;32(8):1222-7.

65. Zhang HM, Wang XT, Zhang LN, He W, Zhang Q, Liu DW. Left ventricular longitudinal systolic function in septic shock patients with normal ejection fraction: a case-control study. Chin Med J. 2017;130(10):1169-74.

66. Furian T, Aguiar C, Prado K, Ribeiro RV, Becker L, Martinelli N, Clausell N, Rohde LE, Biolo A. Ventricular dysfunction and dilation in severe sepsis and septic shock: relation to endothelial function and mortality. J Crit Care. 2012; 27(3):319 e319-5.

67. Vallabhajosyula S, Kumar M, Pandompatam G, Sakhuja A, Kashyap R, Kashani K, Gajic O, Geske JB, Jentzer JC. Prognostic impact of isolated right ventricular dysfunction in sepsis and septic shock: an 8-year historical cohort study. Ann Intensive Care. 2017;7(1):94

68. Wu AH. Increased troponin in patients with sepsis and septic shock: myocardial necrosis or reversible myocardial depression? Intensive Care Med. 2001;27(6):959-61.

69. Cheng $H$, Fan WZ, Wang SC, Liu ZH, Zang HL, Wang LZ, Liu HJ, Shen $\mathrm{XH}$, Liang SQ. N-terminal pro-brain natriuretic peptide and cardiac troponin I for the prognostic utility in elderly patients with severe sepsis or septic shock in intensive care unit: A retrospective study. J Crit Care. 2015;30(3):654 e659-14.

70. Rosjo H, Varpula M, Hagve TA, Karlsson S, Ruokonen E, Pettila V, Omland T. Circulating high sensitivity troponin $T$ in severe sepsis and septic shock: distribution, associated factors, and relation to outcome. Intensive Care Med. 2011;37(1):77-85
71. Vallabhajosyula S, Sakhuja A, Geske JB, Kumar M, Poterucha JT, Kashyap R, Kashani K, Jaffe AS, Jentzer JC. Role of admission troponin-T and serial troponin-T testing in predicting outcomes in severe sepsis and septic shock. J Am Heart Assoc. 2017;6(9) https://doi.org/10.1161/JAHA.117.005930.

72. Masson S, Caironi P, Fanizza C, Carrer S, Caricato A, Fassini P, Vago T, Romero M, Tognoni G, Gattinoni L, et al. Sequential N-terminal pro-B-type natriuretic peptide and high-sensitivity cardiac troponin measurements during albumin replacement in patients with severe sepsis or septic shock. Crit Care Med. 2016:44(4):707-16.

73. de Lemos JA, McGuire DK, Drazner MH. B-type natriuretic peptide in cardiovascular disease. Lancet (London, England). 2003;362(9380):316-22.

74. Richards AM, Crozier IG, Yandle TG, Espiner EA, Ikram H, Nicholls MG. Brain natriuretic factor: regional plasma concentrations and correlations with haemodynamic state in cardiac disease. Br Heart J. 1993;69(5):414-7.

75. Varpula M, Pulkki K, Karlsson S, Ruokonen E, Pettila V. Predictive value of $\mathrm{N}$-terminal pro-brain natriuretic peptide in severe sepsis and septic shock. Crit Care Med. 2007;35(5):1277-83.

76. Ikonomidis I, Nikolaou M, Dimopoulou I, Paraskevaidis I, Lekakis J, Mavrou I, Tzanela M, Kopterides P, Tsangaris I, Armaganidis A, et al. Association of left ventricular diastolic dysfunction with elevated NT-pro-BNP in general intensive care unit patients with preserved ejection fraction: a complementary role of tissue Doppler imaging parameters and NT-pro-BNP levels for adverse outcome. Shock (Augusta, Ga). 2010;33(2):141-8.

77. Ostermann M, Ayis S, Tuddenham E, Lo J, Lei K, Smith J, Sanderson B, Moran C, Collinson P, Peacock J, et al. Cardiac troponin release is associated with biomarkers of inflammation and ventricular dilatation during critical illness. Shock (Augusta, Ga). 2017;47(6):702-8.

78. Nizamuddin J, Mahmood F, Tung A, Mueller A, Brown SM, Shaefi S, O'Connor M, Talmor D, Shahul S. Interval changes in myocardial performance index predict outcome in severe sepsis. J Cardiothorac Vasc Anesth. 2017;31(3):957-64.

79. Velissaris D, Pierrakos C, Scolletta S, De Backer D, Vincent JL. High mixed venous oxygen saturation levels do not exclude fluid responsiveness in critically ill septic patients. Crit Care. 2011;15(4):R177.

80. Sanfilippo F, Santonocito C, Morelli A, Foex P. Beta-blocker use in severe sepsis and septic shock: a systematic review. Curr Med Res Opin. 2015; 31(10):1817-25.

81. Zangrillo A, Putzu A, Monaco F, Oriani A, Frau G, De Luca M, Di Tomasso N, Bignami E, Lomivorotov $V$, Likhvantsev $V$, et al. Levosimendan reduces mortality in patients with severe sepsis and septic shock: A meta-analysis of randomized trials. J Crit Care. 2015;30(5):908-13.

82. Gordon AC, Perkins GD, Singer M, McAuley DF, Orme RM, Santhakumaran S, Mason AJ, Cross M, Al-Beidh F, Best-Lane J, et al. Levosimendan for the prevention of acute organ dysfunction in sepsis. N Engl J Med. 2016; 375(17):1638-48. 